Rozgonjuk, D., Ryan, T., Kuljus, J. K., Täht, K., \& Scott, G. G. (2019). Social comparison orientation mediates the relationship between neuroticism and passive Facebook use. Cyberpsychology: Journal of Psychosocial Research on Cyberspace, 13(1), article 2. http://dx.doi.org/10.5817/CP2019-1-2

\title{
Social comparison orientation mediates the relationship between neuroticism and passive Facebook use
}

\author{
Dmitri Rozgonjuk ${ }^{1,2}$, Tracii Ryan ${ }^{3}$, Joosep Kristjan Kuljus ${ }^{1}$, Karin Täht ${ }^{1}$, \& Graham G. Scott ${ }^{4}$ \\ ${ }^{1}$ Institute of Psychology, University of Tartu, Tartu, Estonia \\ 2 Department of Psychology, University of Toledo, Toledo, Ohio, USA \\ ${ }^{3}$ Centre for the Study of Higher Education, Graduate School of Education, The University of Melbourne, Melbourne, Australia \\ ${ }^{4}$ School of Media, Culture, \& Society, University of the West of Scotland, Paisley, UK
}

\begin{abstract}
Passive Facebook use, which involves engaging in non-socially orientated behavior on the popular social networking site, is associated with a range of negative outcomes, including social anxiety, loneliness, jealousy, and depressed mood. Research indicates that passive Facebook use may also be related to a tendency to engage in social comparison with others. In addition, there is some evidence that this tendency is more prevalent in individuals high in the personality trait neuroticism. The aim of this study was to investigate the relationships between passive Facebook use, neuroticism, and social comparison orientation (SCO). In addition, we explored whether SCO mediates the potential relationship between neuroticism and passive Facebook use. In a crosssectional study, 318 Estonian Facebook users completed the Multidimensional Scale of Facebook Use (to ascertain passive Facebook use), the Extra Short Big Five Personality Inventory, and the lowa-Netherlands Comparison Orientation Scale. The results revealed positive bivariate-correlations between passive Facebook use, neuroticism, and SCO. In addition, SCO mediated the relationship between neuroticism and passive Facebook use. These findings suggest that people higher in neuroticism are more prone to social comparison, which is associated with passive Facebook use. These findings are discussed, and several directions for future research are provided.
\end{abstract}

Keywords: Neuroticism, passive Facebook use, social comparison orientation

\section{Introduction}

Social Networking Sites (SNSs) are increasing in number and popularity, and are being progressively utilized for educational and employment purposes in addition to their primary function of social relationship maintenance (Scott \& Ravenscroft, 2017). As Facebook is the world's most popular SNS, with an active membership of over two billion in 2018 (Facebook Newsroom, 2018), scholars from various disciplines have been interested in understanding the motivations and outcomes of its use.

Currently, Facebook use is understood to facilitate both positive and negative outcomes (Kross et al., 2013; Valenzuela, Park, \& Kee, 2008). On the one hand, Facebook use has been associated with outcomes such as greater life satisfaction (Grieve, Indian, Witteveen, Anne Tolan, \& Marrington, 2013), increased levels of involvement in extra-curricular activities in college students (Junco, 2012), higher classroom motivation and a more positive classroom environment (Mazer, Murphy, \& Simonds, 2007), and more frequent engagement in political and civic action (Park, Kee, \& Valenzuela, 2009). On the other hand, Facebook use is also associated with increased jealousy and decreased life satisfaction (Krasnova, Wenninger, Widjaja, \& Buxmann, 2013; Muise, Christofedes, \& Desmaris, 
2009), substance use (Clayton, Osborne, Miller, \& Oberle, 2013), and a decline in subjective well-being (Kross et al., 2013).

As research on Facebook use continues to amass, contradictory results are becoming increasingly evident. For example, one study revealed that Facebook use results in lower self-esteem (Mehdizadeh, 2010), while another found that it could be especially beneficial to users with low self-esteem by increasing their social capital (Ellison, Steinfield, \& Lampe, 2007). Furthermore, Facebook use has been linked to lower levels of anxiety, depression, and loneliness in several studies (Deters \& Mehl, 2013; Grieve et al., 2013), while others have found that it can lead to increased anxiety (Clayton et al., 2013), depression (Blease, 2015), and loneliness (Song et al., 2014).

In an effort to make sense of these conflicting outcomes, more recent Facebook research has placed increasing focus on examining the differences between specific types of Facebook users and behaviors. For example, it is known that socio-demographic factors, including age and gender, are related to different levels of social media engagement; typically females and younger people use more social media (Kuss \& Griffiths, 2011; Odgers, 2018). There is also a strong relationship between personality characteristics and Facebook use, and individual differences may be differentially associated with positive and negative outcomes (Chow \& Wan, 2017; Ryan, Allen, Gray, \& Mclnerney, 2017). Scholars have also begun to recognize the importance of distinct patterns of Facebook use (Frison \& Eggermont, 2015), and have called for future research into the negative outcomes of Facebook to take these differences into account (Appel, Gerlach, \& Crusius, 2016). This is because there is emerging evidence that positive outcomes are related to active social behavior on Facebook, while more passive behavior is associated with negative outcomes (e.g., Burke \& Kraut, 2016; Frison \& Eggermont, 2015). In fact, Facebook recently publically encouraged its users to use Facebook in more socially meaningful ways (e.g., by posting updates and leaving comments) to avoid potential decreases in wellbeing (Facebook Newsroom, 2017).

Clearly, there is a need for research that examines individual differences, characteristics, motivations, and behaviors to better understand the negative outcomes of Facebook use (Appel et al., 2016). In response, this study investigates how passive Facebook use is associated with two characteristics which have been linked to negative outcomes: the personality factor neuroticism, and tendency to engage in social comparison with others.

\section{Passive Facebook Use}

Frison and Eggermont (2015) proposed a multidimensional model which categorizes Facebook use activities into three types: active-public (e.g., interacting with posts and posting), active-private (e.g., chatting with others), and passive (e.g., browsing the News Feed and other people's profile). Passive behavior, also known as surveillance behavior or 'lurking' (Burke, Marlow, \& Lento, 2010; Clerkin, Smith, \& Hames, 2013; Fox \& Warber, 2013) allows users to keep track of both friendship and romantic relationships without interacting with others directly (Bryant, Marmo, \& Ramirez, 2011; Joinson, 2008; Tokunaga, 2011). Although the proportion of Facebook users engaging in these different patterns of behavior has not been investigated, up to $90 \%$ of users of other social media sites (e.g., YouTube, Twitter) passively consume the product without engaging with it (Anand, Venkataraman, Subbalakshmi, \& Chandramouli, 2015). It is therefore reasonable to assume that a significant proportion of Facebook users are passive users rather than active participants on the site.

Given the potential for passive behavior on Facebook, it is important that the consequences of such activity are investigated. Whereas users engage in active Facebook activity to self-present, share information, and connect with others (Tosun, 2012), common motivations for engaging in passive behavior are to reduce uncertainty, and to compare oneself to others (McEwan, 2013). However, such behavior has been linked with negative outcomes, such as increased social anxiety (Erwin, Turk, Heimberg, Fresco, \& Hantula, 2004; Shaw, Timpano, Tran, \& Joormann, 2015), weaker ties with online friends, increased loneliness (Burke et al., 2010), decreased social wellbeing (Qiu, Lin, Leung, \& Tov, 2012), jealousy (Muise et al., 2009), decreased life satisfaction (Krasnova et al., 2013; Verduyn et al., 2015), and depressed mood in adolescent females (Frison \& Eggermont, 2016). Therefore, there is a need for psychologists to better under the relationship between decreased mental health and passive Facebook use (Verduyn, Ybarra, Résibois, Jonides, \& Kross, 2017). 


\section{Social Comparison Orientation}

The drive to compare oneself with others is commonly known as social comparison (Festinger, 1954). This behavior allows individuals to evaluate their own abilities, traits, and emotions in contrast with others, as well as enhancing their self-esteem and improving decision making (Lee, 2014; Mussweiler, Ruter, \& Epstude, 2006; Schachter, 1959; Thornton \& Arrowood, 1966). Individuals can either engage in social comparison in an upwards (vs. those in better situations) or downwards (vs. those in worse situations) direction (Mussweiler et al., 2006). The act of upward social comparison can offer psychological benefits, such as deepening self-knowledge and contributing to selfimprovement (Buunk \& Gibbons, 2007); however, it has also been associated with negative outcomes. For example, if individuals compare themselves with someone who appears to be doing much better in some aspect of life than they are, they may experience jealousy and envy.

Early theorists proposed contrast effects, suggesting that upwards comparisons lead to negative reactions, and downwards comparisons to positive ones (Wills, 1981). However, recent studies have focused on the effects of individual differences in relation to how frequently individuals engage in, and how they react to, social comparisons. In these studies, individuals often identified with, rather than contrasted against, the object of comparison (Buunk \& Ybema, 1997; Ybema \& Buunk, 1995). Social comparison orientation (SCO) is an individual's tendency to engage in social comparisons (Bogart, Benotsch, \& Pavlovic, 2004; Buunk, Zurriaga, Gonzalez-Roma, \& Subirats, 2003; Buunk, Zurriaga, Peíró, Nauta, \& Gosalvez, 2005; Gibbons \& Buunk, 1999). Individuals vary in their SCO, and research suggests that there is a relationship between personality and SCO (Buunk \& Gibbons, 2007). In particular, SCO is more prevalent among people with high levels of neuroticism, narcissism, anxiety, and low self-esteem (Bogart et al., 2004).

SNSs like Facebook are ideal platforms for social comparison, and tendency to engage in social comparison is associated with Facebook use (Frison \& Eggermont, 2016; Lee, 2014), particularly heavy Facebook use (Jang, Park, \& Song, 2016; Lee, 2014; Ozimek \& Förster, 2017; Vogel, Rose, Okdie, Eckles, \& Franz, 2015). Given the prevalence of SNS use, and the fact that users typically self-present honestly, such sites are a potentially valuable source of social information (Back et al., 2010). However, though users do not generally project false personalities online, they tend to selectively share content, selecting flattering photographs of themselves, and updating their status to reflect positive rather than negative experiences (Brandt, Vonk, \& van Knippenberg, 2009; Ellison, Heino, \& Gibbs, 2006). Thus, social comparison on SNSs is likely to be upwards rather than downwards, as profiles are typically optimized and users appear happier online than they are offline (Qiu et al., 2012). However, such behavior has been associated with ruminations which lead to increased depressive symptoms (Feinstein et al., 2013), as well as negative wellbeing and psychological distress (Jang et al., 2015; Lee, 2014; Gerson, Plagnol, \& Corr, 2016). Indeed, a recent critical review highlights that "passively browsing Facebook has negative consequences for people who naturally tend to engage in social comparisons" (Verduyn et al., 2017, p.291).

Given the proposed link between frequent upwards comparisons and negative well-being; researchers have examined the psychological outcomes of social comparison behavior on Facebook (for more on this see Verduyn et al., 2017). Such research has repeatedly indicated that there is an association between SCO and decreased psychological wellbeing. For example, Frison and Eggermont (2016) reported that experiencing negative affective reactions after engaging in social comparison on Facebook predicted decreases in life satisfaction, while de Vries and Kühne (2015) found a relationship between Facebook use, frequency of negative social comparisons, and lower self-perceptions, particularly among unhappy individuals. In a focus group study, Fox and Moreland (2015) revealed that Facebook enabled constant social comparisons with others, which lead to feelings of envy, while (Yang, 2017) reported that the relationship between SCO and envy is partly mediated by passive social media use. This was among the most commonly experienced stressors associated with Facebook use; however, participants stated that they felt pressure to continue to access SNSs despite these negative emotions. Finally, a review study by Appel et al. (2016) argues that passive Facebook use predicts social comparison behavior, which in turns mediates negative affective reactions, including depression. This suggests that there is value in further investigating the relation between passive use of Facebook and SCO. 


\section{Neuroticism}

Neuroticism is a personality trait exemplified by a tendency to experience emotional instability and negative affect (Goldberg, 1993). Individuals high in this trait are more likely to experience feelings of fear, jealousy, stress, and vulnerability (Judge \& Bono, 2000). High levels of neuroticism are also associated with sensitivity to criticism and rejection, lower subjective wellbeing, lower self-esteem, difficulty with romantic and social relationships, anxiety and personality disorders, and depression (Amirazodi \& Amirazodi, 2011; Ozer \& Benet-Martinez, 2006). High levels of neuroticism have been linked to the maladaptive online behavior of cyberloafing, which involves procrastinating on the internet instead of working (Varghese \& Barber, 2017). As previously noted, Facebook allows users to passively monitor social and romantic relationships (Bryant et al., 2011), to compare oneself to others, and to seek validation and reduce uncertainty (McEwan, 2013). Arguably, these are all behaviors that would be attractive to individuals that are high in neuroticism. As such, researchers are beginning to explore the possibility that neurotic individuals are likely to engage in passive Facebook use.

Thus far, research has confirmed that there is a connection between neuroticism and particular types of Facebook use. For example, there is an association between neuroticism and high frequency Facebook use (Caci, Cardaci, Tabacchi, \& Scrima, 2014). Individuals high on neuroticism also tend to prefer using Facebook to engage in asynchronous communication (i.e. by posting on their timeline rather than chatting via Messenger), as this mode of communication allows them to control the timing, pace, and content of their social interactions (Ross et al., 2009; Ryan \& Xenos, 2011). Neuroticism is also positively correlated with more frequent use of Facebook in socially passive ways, such as playing games and following fan pages (Ryan \& Xenos, 2011). Several recent studies have also found that neuroticism is related to increased feelings of envy as a result of social comparisons activated by Facebook use (Chow \& Wan, 2017; Wallace, James, \& Warkentin, 2017). It is unclear if there is any interaction between neuroticism and user gender on Facebook use; gender was found to moderate the effect of neuroticism on number of Facebook friends and photos (Basak, Yasar, \& Calisir, 2018), with emotionally stable females having more friends, and neuroticism being a stronger predictor among male than female users, but there has been no moderating impact of gender found on the effect of personality on Facebook use (El-Tah \& Jaradat, 2018).

Individuals who are high in neuroticism are more likely to focus on negative interpretations of social comparison (Van Der Zee, Buunk, Sanderman, Botke, \& Van Den Bergh, 1999), and be more likely to identify with downwards rather than upwards comparison targets (Buunk, Van der Zee, \& VanYperen, 2001), suggesting these individuals are at risk of experiencing negative outcomes resulting from social comparison. Indeed, Chow and Wan (2017) reported associations between neuroticism, envy, engaging in social comparison on Facebook, and lower wellbeing. The authors proposed that neurotic individuals may spend more time engaging in passive behavior on Facebook, such as looking at other users' photos and posts. Furthermore, their tendency to feel envy may trigger rumination or negative thoughts, thus leading to reductions in well-being. However, previous studies have not investigated how these comparisons are related specifically to passive Facebook use.

\section{Rationale for this Study}

SCO has been associated with heavy Facebook use (Ozimek \& Forster, 2017), and engaging in social comparisons on Facebook has also been linked to negative wellbeing (Gerson et al., 2016). Research has also indicated that SCO is associated with passive Facebook use (Appel et al., 2016) and neuroticism (Buunk \& Gibbons, 2006) due to the fact that individuals higher in this trait are less confident and more likely to set high goals, leading them to seek comparison with others (Buunk et al., 2001; Van Der Zee et al., 1999).

Although previous studies have reported relationships between Facebook use and neuroticism (Correa, Bachmann, Willard Hensley, \& Gil de Zúñiga, 2013), studies have not examined if neuroticism, SCO, and passive Facebook use are related in multivariate analyses. By measuring the neuroticism, passive Facebook use, and SCO of Facebook users, it would be possible to demonstrate the relationship between these three variables and investigate the presence of a mediating relationship. This will provide insight into potential drivers of passive Facebook use; a pattern of behavior established to have negative consequences compared to more active, sociallyengaging online behaviors. 
Our proposed research model is outlined in Figure 1 where, in addition to the constructs of interest, we included age and gender as covariates, as research has shown that these socio-demographics might be relevant in social media engagement (Kuss \& Griffiths, 2011). In this model, SCO is one manifestation of the heightened anxiety experienced by individuals high in neuroticism and, as such, encourages the passive, rather than active, consumption of Facebook content. This research model stems from the scientific literature, as neuroticism has been shown to be related to more frequent social comparisons (Buunk \& Gibbons, 2006), more frequent social comparison appears to be related to more Facebook use (Jang et al., 2016), more frequent social comparison has been related to passive Facebook use and negative consequences (Verduyn et al., 2017), and neuroticism has been found to be related to more passive Facebook use (Ryan \& Xenos, 2011). We argue, therefore, that it makes sense to test these variables in one mediation model.

It should be noted that we include SCO as a mediator in this model rather than neuroticism, as neuroticism is believed to be a core personality trait that remains relatively stable over one's life span (McCrae et al., 2000). Our hypothesized model relies on the logic that a core characteristic (neuroticism) may shape one's beliefs and attitudes (social comparison orientation) that may, in turn, shape one's behavior (passive Facebook use).

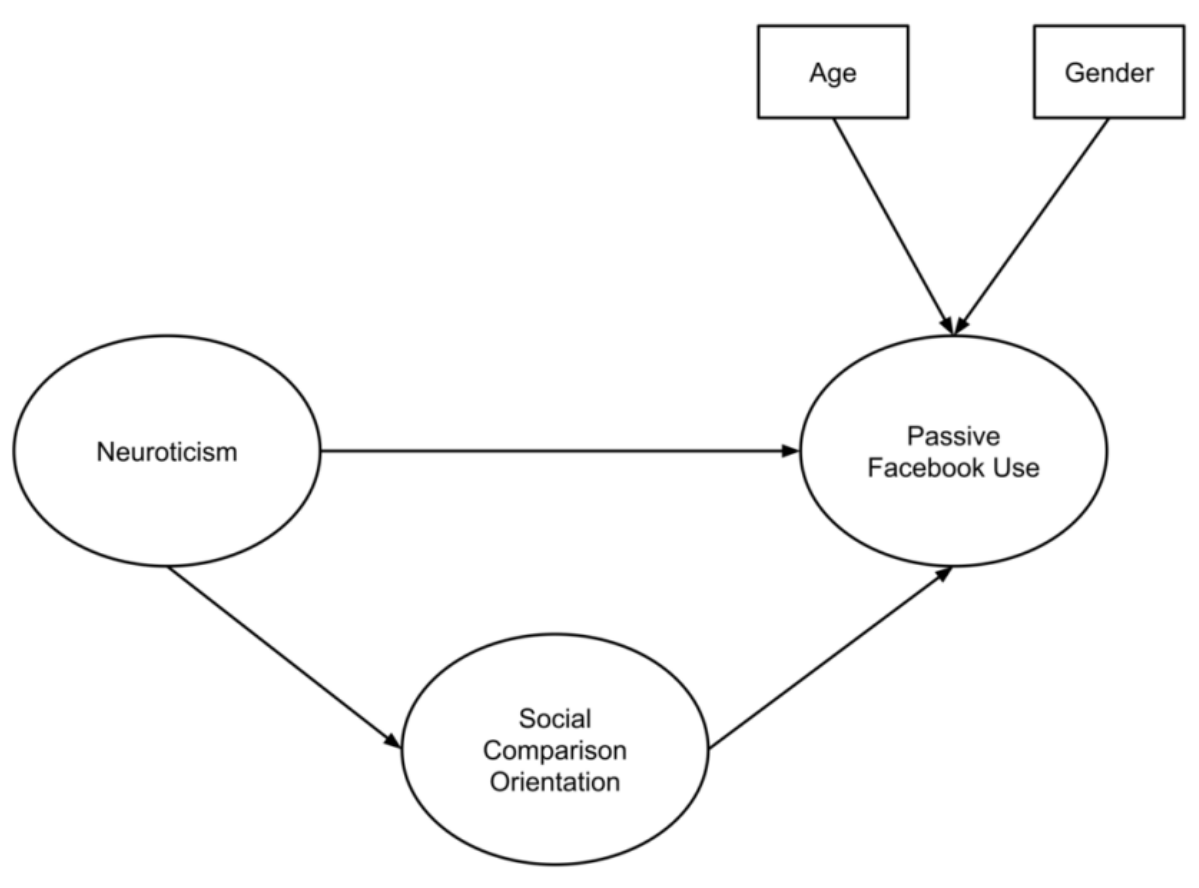

Figure 1. The hypothesized research model with covariates.

\section{Aims and Hypotheses}

The aim of this research is to investigate the relationship between passive Facebook use and neuroticism, and to explore the possible mediating role played by SCO. We expect that individuals with higher levels of neuroticism will be more prone to comparing themselves with others, and will meet this need through passive observation on Facebook. Facebook users high in neuroticism utilize the site regularly, typically revisiting it frequently, but staying connected for short periods of time (Correa et al., 2013). It is possible that this pattern of behavior is a result of high levels of anxiety in individuals with higher neuroticism traits that may be explained by an increased need for social support (Ross et al., 2009). Indeed, individuals high in neuroticism are more likely to use the internet in an effort to reduce loneliness (Butt \& Phillips, 2008) but they also experience low levels of perceived social support (Swickert, Hittner, Harris, \& Herring, 2002). Therefore, we propose the following hypotheses:

H1: Neuroticism will be positively correlated with passive Facebook use. 
Previous research has indicated that neuroticism is associated with use and frequency of Facebook use (Correa et al., 2013). Given that Facebook allows users to easily engage in passive surveillance behavior, we propose that individuals high in neuroticism would engage in passive Facebook use.

\section{H2: SCO will be positively correlated with passive Facebook use.}

The aim of social comparison is to gain information about others in order to accurately compare oneself to them (Festinger, 1954). This could be for the purpose of self-evaluation or to improve self-esteem or decision making (Lee, 2014; Mussweiler et al., 2006). To accomplish this Facebook users will 'lurk' and view information posted by others.

H3: Social comparison will mediate the relationship between neuroticism and passive Facebook use.

\section{Method}

\section{Participants}

An online survey was completed by 329 Estonian Internet users. Data from 11 respondents were excluded as they did not meet the requirements of the study (e.g., they did not use Facebook, or provided missing data in key constructs, etc.). The final sample consisted of 318 respondents, of whom 280 (88.1\%) were women. Ages ranged from 18 to 64 years $(M=26.74, S D=9.02)$.

\section{Procedure}

Participants were recruited to complete an online survey through advertisements posted on some of the authors' Facebook accounts. The snowball sampling approach was also used, as potential participants were also encouraged to "share" the study participation advertisement on their own Facebook pages. The survey asked participants about their sociodemographic information (e.g., age, gender), and then included the following measures (for descriptive and internal reliability statistics for the measures of the effective sample, see Table 1).

\section{Measures}

Multidimensional Scale of Facebook Use (MSFU; Frison and Eggermont, 2015). Ten-item scale of Facebook use with three subscales: (a) active-public (two items; Cronbach's a =.59), (b) active-private (three items; $a=.86$ ), and (c) passive (five items; $\alpha=.86$ ). Items were measured using a 7-point scale of frequency, where $1=$ never and $7=$ several times a day. The MSFU scale was adapted to Estonian in Pahker (2016). In the current study, only passive Facebook use is of interest. It should be noted that Frison and Eggermont (2015) initially proposed five items to measure passive Facebook use subscale, but they eventually excluded one item (How often do you read your news feed?). For this study, we felt that this item is reflective of passive Facebook use behavior. Therefore, we included that item in the subscale.

Extra Short Big Five Personality Inventory (XS5; Konstabel et al., 2017). This shortened version of the 60-item Short Big Five Personality Inventory (Konstabel, Lönnqvist, Walkowitz, Konstabel, \& Verkasalo, 2012) measures personality dimensions using 30 items on a 7 -point scale $(-3=$ totally disagree $;+3=$ totally agree $)$. Six items correspond to each dimension: extraversion $(\alpha=.75)$, neuroticism $(\alpha=.76)$, openness to experience $(\alpha=.66)$, agreeableness $(\alpha=.57)$, and conscientiousness $(\alpha=.70)$. Only the neuroticism subscale is included in the current paper.

lowa-Netherlands Comparison Orientation Scale (INCOM; Gibbons \& Buunk, 1999). This is an 11-item, unidimensional scale measuring social comparison orientation on a 5-point scale ( $1=1$ disagree strongly, $5=1$ agree strongly) $(\alpha=.83)$. The scale has been validated against actual social comparison behavior (Gibbons \& Buunk, 1999), and adapted to Estonian in Lehtmets (2017). 


\section{Data Analysis}

Data analysis was conducted using Mplus version 8 (Muthén \& Muthén, 2017), and RStudio version 3.2.3 (R Core Team, 2017). To test $\mathrm{H} 1$ and $\mathrm{H} 2$, Pearson product-moment correlation analyses were used.

We first conducted a series of confirmatory factor analyses to test the model fit of measurement models for each scale. We used the weighted least squares estimation with a mean- and variance-adjusted (WLSMV) chi-square, treating the items of neuroticism, SCO, and passive Facebook use as ordinal, thus involving a polychoric covariance matrix and probit-based factor loadings (DiStefano \& Morgan, 2014; Wirth \& Edwards, 2007).

Based on the model fit of latent scale scores, we then used the same estimation model for the mediation model (testing H3), where the latent score of neuroticism was used as a predictor, latent SCO scale score as the mediator, and latent passive Facebook use score as the outcome variable. To test the indirect effect in the mediation model, the cross-product of direct path coefficients were calculated, computing indirect effect's standard error with Delta method over 1000 bootstrapped samples (MacKinnon, 2008)

Goodness of fit was judged on standard thresholds: (a) Comparative Fit Index (CFI) $\geq .90$, Tucker-Lewis Index (TLI) $\geq .90$, and root mean square error of approximation (RMSEA) $\leq .08$ (Hu \& Bentler, 1999).

\section{Results}

\section{Relationships Between Variables}

Correlations, means and standard deviations, and internal consistencies are presented in Table 1. Internal consistency was acceptable for the subscales of passive Facebook use and neuroticism, and good for the social comparison scale. As shown, there were significant positive correlations between all variables. Correlations and p-values for relationships between variables in Table 1 and other personality and Facebook use variables are presented in Supplementary Table A1.

Table 1. Zero Order Correlations, Means, Standard Deviations, and Internal Consistencies of Scales and Subscales for the Sample of This Study.

\begin{tabular}{|c|c|c|c|c|c|c|c|}
\hline Variable & 1 & 2 & Min & Max & $M$ & $S D$ & $a$ \\
\hline 1 Passive Facebook use & & & 6 & 30 & 17.31 & 4.89 & .78 \\
\hline 2 Neuroticism & $.26 * * *$ & & -18 & 16 & -2.94 & 6.55 & .76 \\
\hline 3 Social Comparison Orientation & $.37 * \star \star$ & $.40 * \star \star$ & 17 & 45 & 32.82 & 4.48 & .86 \\
\hline
\end{tabular}

Note: $N=318 .{ }^{*} p<.05, * \star p<.01, * \star \star p<.001$

\section{Structural Equation Modelling and Mediation Analysis Results}

CFA for the 5-item passive Facebook use scale showed adequate fit, $\chi^{2}(5, N=318)=92.49, p<.001, \mathrm{CFI}=.96$, TLI $=.93, \mathrm{RMSEA}=.24,90 \% \mathrm{Cl}[.19, .28]$; the 4-item passive Facebook use scale used in Frison and Eggermont (2015) showed poorer fit, $\chi^{2}(2, N=318)=86.05, p<.001, \mathrm{CFI}=.97, \mathrm{TLI}=.89$, RMSEA $=.36,90 \% \mathrm{Cl}[.30, .43]$. The six-item Neuroticism scale showed good fit, $\chi^{2}(9, N=318)=31.04, p<.001, \mathrm{CFI}=.98, \mathrm{TLI}=.97, \mathrm{RMSEA}=.09,90 \% \mathrm{Cl}[.06$, .12]. The 11-item SCO scale showed adequate fit, $\chi^{2}(44, N=318)=280.64, p<.001, \mathrm{CFI}=.93, \mathrm{TLI}=.91, \mathrm{RMSEA}=$ $.13,90 \% \mathrm{Cl}[.12, .15]$.

Next, we conducted mediation analyses with latent scores where Neuroticism was the predictor, SCO the mediator, and passive Facebook use the outcome variable. In addition, we included age and gender as covariates for passive use, because these characteristics have shown to be predictors of social media engagement (Kuss \& Griffiths, 2011). The fit indices provided evidence for a good fit, $\chi^{2}(248, N=318)=591.85, p<.001, \mathrm{CFI}=.94, \mathrm{TLI}=$ 
$.94, \mathrm{RMSEA}=.07,90 \% \mathrm{Cl}[.06, .07]$. The model results are presented in Table 2 , and the graphical depiction of these results is presented in Figure 2.

There was a positive and statistically significant relationship between neuroticism and SCO, $B=.577, \beta=.640$, standardized $S E=.049, p<.001$, and SCO positively predicted passive Facebook use, $B=.399, \beta=.413$, standardized $S E=.081, p<.001$. However, in this model, neuroticism was not a significant predictor of passive Facebook use, $B$ $=.039, \beta=.045$, standardized $S E=.090, p=.501$. Furthermore, the indirect path from neuroticism to $S C O$ to passive Facebook use was statistically significant, suggesting that SCO completely mediates the relationship between neuroticism and passive Facebook use, $B=.230, \beta=.264$, standardized $S E=.059, p<.001$. Age and gender did not predict passive Facebook use.

Table 2. Results of the Structural Regression Model.

\begin{tabular}{|c|c|c|c|c|}
\hline & \multicolumn{4}{|c|}{ Dependent variable: Passive Facebook use } \\
\hline & Bivariate $B(S E)$ & $\boldsymbol{t}$ & Multivariate $B(S E)$ & $\boldsymbol{t}$ \\
\hline Age & $-.002(.005)$ & -.346 & $-.022(.063)$ & -.348 \\
\hline Gender & $-.155(.144)$ & -1.074 & $-.067(.062)$ & -1.080 \\
\hline Neuroticism & $.039(.080)$ & .491 & $.045(.090)$ & .501 \\
\hline SCO & $.399(.084)$ & $4.766^{\star * *}$ & $.413(.081)$ & $5.087 * * *$ \\
\hline Neuroticism -> SCO & $.577(.063)$ & $9.087 * * *$ & $.640(.049)$ & $12.980 * * *$ \\
\hline Neuroticism -> SCO -> Passive Facebook use & $.230(.055)$ & $4.200 * \star \star$ & $.264(.059)$ & $2.501 * \star \star *$ \\
\hline
\end{tabular}

Note: $N=318$. SCO = social comparison orientation Estimation method: weighted least squares mean- and varaince-adjusted adjusted chi-square (WLSMV). Standard errors bootstrapped over 1000 samples. Model fit indices: $X^{2}(248, N=318)=591.85, p<.001, \mathrm{CFI}=.94, \mathrm{TLI}$ $=.94, \mathrm{RMSEA}=.07,90 \% \mathrm{Cl}[.06, .07]$.

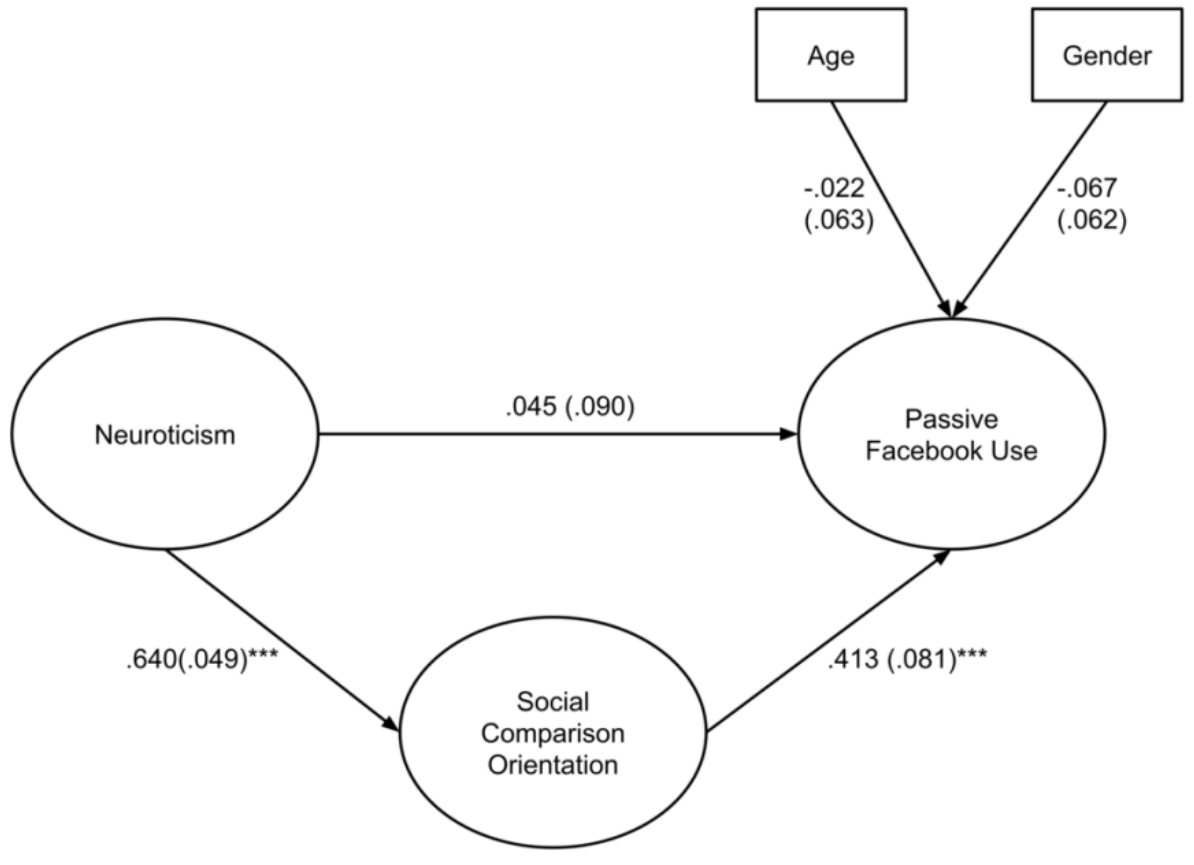

Figure 2. Results of mediation analysis (standardized coefficients with bootstrapped SE). 


\section{Discussion}

The aim of the study was to investigate how neuroticism, social comparison orientation (SCO), and passive Facebook use are associated. Furthermore, it was of interest to study if and how SCO mediates the relationship between neuroticism and passive Facebook use. It should be noted that due to the cross-sectional nature of our study, we caution the readers to keep in mind that the causal directions are hypothesized based on theory and, therefore, no causal relationships can be directly inferred from our results.

\section{Main Findings}

We proposed that passive Facebook use would be positively related to both neuroticism $(\mathrm{H} 1)$ and SCO $(\mathrm{H} 2)$. Our findings support these hypotheses, as both neuroticism and SCO were bivariate-correlated. Facebook affords passive use, or lurking, to fulfil a number of its main functions, such as habitual passing of time, entertainment, and escape (Papacharissi \& Mendelson, 2011). SCO possibly contributes to the gratifications different types of individuals seek from Facebook use and high SCO in users has been linked to higher engagement in passive activity (Frison \& Eggermont, 2015). Passive Facebook use has been associated with a number of negative outcomes, such as increased depression (Feinstein et al., 2013) and negative emotions (Haferkamp \& Kramer, 2011), possibly because lack of online social interactions, and upwards social comparisons, are associated with low perceived levels of online social support (Frison \& Eggermont, 2015). This is particularly pertinent for users who are high in neuroticism, as they are more likely to engage in passive behavior on Facebook, and to experience negative outcomes, such as envy and reduced wellbeing, when they engage in social comparison (Chow \& Wan, 2017; Van Der Zee et al., 1999; Wallace et al., 2017).

We also proposed that SCO mediates the relationship between neuroticism and passive Facebook use $(\mathrm{H} 3)$. The empirical evidence supports this hypothesis. In fact, we found that SCO completely mediates the relationship between neuroticism and passive Facebook use.

\section{Contribution}

The current study contributes to the field of research on individual differences in SNS use. Specifically, this is the first study to investigate how neuroticism, SCO, and passive Facebook use are associated - and whether SCO mediates the relationship between neuroticism and passive Facebook use. Social networking sites like Facebook may be facilitating social comparisons (Frison \& Eggermont, 2016; Lee, 2014) because they allow for feasibility in accessing others' personal information. Because people with higher neuroticism tend to engage more in social comparisons (Van Der Zee et al., 1999), it seems plausible that these individual characteristics and tendencies may be associated with more passive online behavior. However, it would also be interesting to see if these results are replicable in other social networking sites.

Because neuroticism is associated with psychological disorders, especially negative affect-related psychopathologies (Dunkley, Sanislow, Grilo, \& McGlashan, 2009; Saklofske, Kelly, \& Janzen, 1995; Watson, Clark, \& Carey, 1988), it could be that individuals who engage in more passive Facebook use could be experiencing dysfunctional emotion regulation via excessive passive social media use. In fact, according to the Compensatory Internet Use Theory (Kardefelt-Winther, 2014), problematic use of digital technologies may be a maladaptive method for coping with one's negative affect and emotional distress. Therefore, maybe higher levels of passive Facebook use are an indication of these dysfunctionalities and may require interventions, such as behavioral activation (Jacobson, Martell, \& Dimidjian, 2006) or emotion regulation skills training (Berking et al., 2008). Future studies should investigate whether this is the case.

Another possible explanation for the results presented here relates to the concept known as fear of missing out (FOMO). FOMO, which is the distress associated with thoughts of being socially excluded, is known to manifest when Facebook users see posts that indicate their friends are interacting without them. Blackwell, Leaman, Tramposch, Osborne, and Liss (2017) recently found that neuroticism was positively correlated with FOMO, which is unsurprising given that individuals high on this trait tend to experience envy, are sensitive to rejection, and commonly experience conflict in relationships. Further research could explore the potential role that FOMO plays in the relationship between neuroticism, passive Facebook use and SCO. For example, it is possible that neurotic 
individuals are driven by FOMO to regularly monitor what other people are posting by frequently refreshing their Facebook feed (Przybylski, Murayama, DeHaan, \& Gladwell, 2013). Such behavior involves no social interaction, and is therefore a type of passive Facebook use. Through the constant refreshing, individuals are repeatedly exposing themselves to the lives of others - lives that are often highly curated to appear more appealing. This may lead to upwards social comparisons, and subsequent decreases in wellbeing.

\section{Limitations}

This study has some limitations. First, the cross-sectional nature of the data makes it impossible to determine causality in the relationships. We have assumed that neuroticism is a relatively stable personality characteristic (Cobb-Clark \& Schurer, 2012; Specht, Egloff, \& Schmukle, 2011), one's tendency to compare oneself to others is influenced by the level of neuroticism, and these psychological characteristics could lead to behavioral outcomes. However, this model should be tested in a longitudinal, repeated-measures study. Second, our study sample comprised only Estonian Facebook users. Approximately half of the Estonian population actively uses Facebook (NapoleanCat, 2017; Statistia, 2018), emphasizing the prominent role of this SNS in everyday Estonian culture. Although cultural differences may play a role in Facebook use, there is currently no evidence if and how these differences reflect on passive Facebook use, and culture has been demonstrated to have non-significant effects on SCO (though it does influence motivations for social comparison) when comparing American and South Korean samples (Song, Cramer, \& Park, 2018). Therefore, future research could provide answers to questions with regards to cultural differences. Third, our sample was biased towards female participants. That more than $80 \%$ of our sample comprised female participants, does not adequately reflect the demographic breakdown of Estonian Facebook users by gender. It has been reported that although there are more female users in Estonia, the ratio is around 55\% (NapoleonCat, 2017). This discrepancy ought to be kept in mind while generalizing the results of this study for the whole Facebook users' population. Although this may affect the generalizability of the findings to some extent, our results did not show gender to be a significant predictor of passive Facebook use. Fourth, we used self-reported measures that may provide a less accurate insight into Facebook use than behavioral data. However, it ought to be acknowledged that accurate behavioral information about passive Facebook use can be difficult to obtain. One way would be to obtain users' behavioral log data to see their interactions with the social networking site's platform. Subsequent studies may consider this option for a better validation of the findings.

\section{Conclusions}

This study found that, although neuroticism, social comparison, and passive Facebook use are associated in bivariate relationships, social comparison completely mediated the relationship between neuroticism and passive Facebook use. These results provide a novel and useful insight into the potential behavior of Facebook users. Specifically we highlight the link between SCO and a passive style of Facebook use, which has been associated with a number of negative outcomes. Unfortunately, our cross-sectional study design restricts us from causal interpretation; however, we believe that this type of model could be useful in future studies that test the validity of our proposed model. Further research is needed to determine whether the associations reported here are specific to Facebook, or whether they generalize to other SNSs. For example, are these results replicable using behavioral data from other SNSs where multidimensional use is possible (e.g., YouTube, Instagram)? Though the motivations of distinct SNS users differ (Ryan, Chester, Reece, \& Xenos, 2014), these platforms provide similar features for interaction.

\section{References}

Amirazodi, F., \& Amirazodi, M. (2011). Personality traits and self-esteem. Procedia - Social and Behavioral Sciences, 29, 713-716. https://doi.org/10.1016/j.sbspro.2011.11.296

Anand, S., Venkataraman, M., Subbalakshmi, K. P., \& Chandramouli, R. (2015). Spatio-temporal analysis of passive consumption in Internet media. IEEE Transactions on Knowledge and Data Engineering, 27, 2839-2850. https://doi.org/10.1109/tkde.2015.2419653

Appel, H., Gerlach, A. L., \& Crusius, J. (2016). The interplay between Facebook use, social comparison, envy, and depression. Current Opinion in Psychology, 9, 44-49. https://doi.org/10.1016/j.copsyc.2015.10.006 
Back, M. D., Stopfer, J. M., Vazire, S., Gaddis, S., Schmukle, S. C., Egloff, B., \& Gosling, S. D. (2010). Facebook profiles reflect actual personality, not self-idealization. Psychological Science, 21, 372-374.

https://doi.org/10.1177/0956797609360756

Basak, E., Yasar, N. N., \& Calisir, F. (2018). Moderating effect of gender on the relationship between extraversion, neuroticism, conscientiousness and Facebook use. International Journal of Web Based Communities, 14, 257-267. https://doi.org/10.1504/ijwbc.2018.094914

Berking, M., Wupperman, P., Reichardt, A., Pejic, T., Dippel, A., \& Znoj, H. (2008). Emotion-regulation skills as a treatment target in psychotherapy. Behaviour Research and Therapy, 46, 1230-1237.

https://doi.org/10.1016/j.brat.2008.08.005

Blackwell, D., Leaman, C., Tramposch, R., Osborne, C., \& Liss, M. (2017). Extraversion, neuroticism, attachment style and fear of missing out as predictors of social media use and addiction. Personality and Individual Differences, 116, 69-72. https://doi.org/10.1016/j.paid.2017.04.039

Blease, C. R. (2015). Too many 'friends,' too few 'likes'? Evolutionary psychology and 'Facebook depression'. Review of General Psychology, 19, 1-13. https://doi.org/10.1037/gpr0000030

Bogart, L. M., Benotsch, E. G., \& Pavlovic, J. D. P. (2004). Feeling superior but threatened: The relation of narcissism to social comparison. Basic and Applied Social Psychology, 26, 35-44.

https://doi.org/10.1207/s15324834basp2601_4

Brandt, A. C., Vonk, R., \& van Knippenberg, A. (2009). The source effect: Person descriptions by self versus others have differential effects on impression formation. Personality \& Social Psychology Bulletin, 35, 965-977.

https://doi.org/10.1177/0146167209335056

Bryant, E., Marmo, J., \& Ramirez, A. (2011). A functional approach to social networking sites. In K. B. Wright \& L. M. Webb (Eds.), Computer-mediated communication in personal relationships (pp. 3-20). New York, NY: Peter Lang Publishing, Inc.

Burke, M. \& Kraut, R.E. (2016). The relationship between Facebook use and well-being depends on communication type and tie strength. Journal of Computer-Mediated Communication, 21, 265-281.

https://doi.org/10.1111/jcc4.12162

Burke, M., Marlow, C., \& Lento, T. (2010). Social network activity and social well-being. Paper presented at the 2010 ACM Conference on Human Factors in Computing Systems, Atlanta, GA.

Butt, S., \& Phillips, J. G. (2008). Personality and self reported mobile phone use. Computers in Human Behavior, 24, 346-360. https://doi.org/10.1016/j.chb.2007.01.019

Buunk, A. P., \& Gibbons, F. X. (2006). Social comparison orientation: A new perspective on those who do and those who don't compare with others. In S. Guimond (Ed.), Social Comparison and Social Psychology: Understanding cognition, intergroup relations and culture (pp. 15-33). Cambridge, UK: Cambridge University Press.

Buunk, A. P., \& Gibbons, F. X. (2007). Social comparison: The end of a theory and the emergence of a field. Organizational Behavior and Human Decision Processes, 102, 3-21. https://doi.org/10.1016/j.obhdp.2006.09.007

Buunk, B. P., Van der Zee, K., \& VanYperen, N. W. (2001). Neuroticism and social comparison orientation as moderators of affective responses to social comparison at work. Journal of Personality, 69, 745-762. https://doi.org/10.1111/1467-6494.695162

Buunk, B. P., \& Ybema, J. F. (1997). Social comparisons and occupational stress: The identification-contrast model. In B. P. Buunk \& F. X. Gibbons (Eds.), Health, coping, and well-being: Perspectives from social comparison theory (pp. 359-388). Hillsdale, NJ: Erlbaum. 
Buunk, B. P., Zurriaga, R., Gonzalez-Roma, V., \& Subirats, M. (2003). Engaging in upward and downward comparisons as a determinant of relative deprivation at work: A longitudinal study. Journal of Vocational Behavior, 62, 370-388. https://doi.org/10.1016/s0001-8791(02)00015-5

Buunk, B. P., Zurriaga, R., Peíró, J. M., Nauta, A., \& Gosalvez, I. (2005). Social comparisons at work as related to a cooperative social climate and to individual differences in social comparison orientation. Applied Psychology, 54, 61-80. https://doi.org/10.1111/j.1464-0597.2005.00196.x

Caci, B., Cardaci, M., Tabacchi, M. E., \& Scrima, F. (2014). Personality variables as predictors of Facebook usage. Psychological Reports: Relationships \& Communications, 114, 528-539. https://doi.org/10.2466/21.09.PR0.114k23w6

Chow, T. S., \& Wan, H. Y. (2017). Is there any 'Facebook Depression'? Exploring the moderating roles of neuroticism, Facebook social comparison and envy. Personality and Individual Differences, 119, 277-282. https://doi.org/10.1016/j.paid.2017.07.032

Clayton, R. B., Osborne, R. E., Miller, B. K., \& Oberle, C. D. (2013). Loneliness, anxiousness, and substance use as predictors of Facebook use. Computers in Human Behavior, 29, 687-693. https://doi.org/10.1016/j.chb.2012.12.002

Clerkin, E. M., Smith, A. R., \& Hames, J. L. (2013). The interpersonal effects of Facebook reassurance seeking. Journal of Affective Disorders, 151, 525-530. https://doi.org/10.1016/j.jad.2013.06.038

Cobb-Clark, D. A., \& Schurer, S. (2012). The stability of big-five personality traits. Economics Letters, 115, 11-15. https://doi.org/10.1016/j.econlet.2011.11.015

Correa, T., Bachmann, I., Willard Hensley, A., \& Gil de Zúñiga, H. (2013). Personality and social media use. In E. Y. Li, S. Loh, C. Evans \& F. Lorenzi (Eds.), Organizations and social networking: Utilizing social media to engage consumers (pp. 41-61). Hershey: IGI Global.

de Vries, D. A., \& Kühne, R. (2015). Facebook and self-perception: Individual susceptibility to negative social comparison on Facebook. Personality and Individual Differences, 86, 217-221.

https://doi.org/10.1016/j.paid.2015.05.029

Deters, F. G., \& Mehl, M. R. (2013). Does posting Facebook status updates increase or decrease loneliness? An online social networking experiment. Social Psychological and Personality Science, 4, 579-586.

https://doi.org/10.1177/1948550612469233

DiStefano, C., \& Morgan, G. B. (2014). A comparison of diagonal weighted least squares robust estimation techniques for ordinal data. Structural Equation Modeling: A Multidisciplinary Journal, 21, 425-438.

https://doi.org/10.1080/10705511.2014.915373

Dunkley, D. M., Sanislow, C. A., Grilo, C. M., \& McGlashan, T. H. (2009). Self-criticism versus neuroticism in predicting depression and psychosocial impairment for 4 years in a clinical sample. Comprehensive Psychiatry, 50, 335-346. https://doi.org/10.1016/j.comppsych.2008.09.004

El-Tah, Z. K. R., \& Jaradat, M.-I. R. M. (2018). The big five personality traits and their relationship with the intensity of using Facebook: A developing country perspective. International Journal of Business Information Systems, 27, 512-537. https://doi.org/10.1504/ijbis.2018.090290

Ellison, N., Heino, R., \& Gibbs, J. (2006). Managing impressions online: Self-presentation processes in the online dating environment. Journal of Computer-Mediated Communication, 11, 415-441. https://doi.org/10.1111/j.10836101.2006.00020.x

Ellison, N. B., Steinfield, C., \& Lampe, C. (2007). The benefits of Facebook "Friends:" Social capital and college students' use of online social network sites. Journal of Computer-Mediated Communication, 12, 1143-1168.

https://doi.org/10.1111/j.1083-6101.2007.00367.x 
Erwin, B. A., Turk, C. L., Heimberg, R. G., Fresco, D. M., \& Hantula, D. A. (2004). The Internet: Home to a severe population of individuals with social anxiety disorder? Journal of Anxiety Disorders, 18, 629-466.

https://doi.org/10.1016/j.janxdis.2003.08.002

Facebook Newsroom. (2017). Hard questions: Is spending time on social media bad for us? Retrieved from https://newsroom.fb.com/news/2017/12/hard-questions-is-spending-time-on-social-media-bad-for-us/

Facebook Newsroom. (2018). Company info. Retrieved from https://newsroom.fb.com/company-info/

Feinstein, B. A., Hershenberg, R., Bhatia, V., Latack, J. A., Meuwly, N., \& Davila, J. (2013). Negative social comparison on Facebook and depressive symptoms: Rumination as a mechanism. Psychology of Popular Media Culture, 2, 161-170. https://doi.org/10.1037/a0033111

Festinger, L. (1954). A theory of social comparison processes. Human Relations, 7, 117-140.

https://doi.org/10.1177/001872675400700202

Fox, J., \& Moreland, J. J. (2015). The dark side of social networking sites: An exploration of the relational and psychological stressors associated with Facebook use and affordances. Computers in Human Behavior, 45, 168176. https://doi.org/10.1016/j.chb.2014.11.083

Fox, J., \& Warber, K. M. (2013). Romantic relationship development in the age of Facebook: An exploratory study of emerging adults' perceptions, motives, and behaviors. Cyberpsychology, Behavior, and Social Networking, 16, 37. https://doi.org/10.1089/cyber.2012.0288

Frison, E., \& Eggermont, S. (2015). Toward an integrated and differential approach to the relationships between Ioneliness, different types of Facebook use, and adolescents' depressed mood. Communication Research, 1-28. Advanced online publication. https://doi.org/10.1177/0093650215617506

Frison, E., \& Eggermont, S. (2016). "Harder, Better, Faster, Stronger": Negative comparison on Facebook and adolescents' life satisfaction are reciprocally related. Cyberpsychology, Behavior, and Social Networking, 19, 158164. https://doi.org/10.1089/cyber.2015.0296

Gerson, J., Plagnol, A.C., Corr, P.J. (2016). Subjective wellbeing and social media use: do personality traits moderate the impact of social comparison on Facebook? Computers in Human Behavior, 63, 813-822.

https://doi.org/10.1016/j.chb.2016.06.023

Gibbons, F. X., \& Buunk, B. P. (1999). Individual differences in social comparison: Development of a scale of social comparison orientation. Journal of Personality and Social Psychology, 76, 129-142. https://doi.org/10.1037/00223514.76.1.129

Goldberg, L. R. (1993). The structure of phenotypic personality traits. American Psychologist, 48, 26-34. https://doi.org/10.1037/0003-066x.48.1.26

Grieve, R., Indian, M., Witteveen, K., Anne Tolan, G., \& Marrington, J. (2013). Face-to-face or Facebook: Can social connectedness be derived online? Computers in Human Behavior, 29, 604-609.

https://doi.org/10.1016/j.chb.2012.11.017

Haferkamp, N., \& Kramer, N. C. (2011). Social comparison 2.0: Examining the effects of online profiles on socialnetworking sites. Cyberpsychology, Behavior, and Social Networking, 14, 309-314.

https://doi.org/10.1089/cyber.2010.0120

Hu, L. t., \& Bentler, P. M. (1999). Cutoff criteria for fit indexes in covariance structure analysis: Conventional criteria versus new alternatives. Structural Equation Modeling: A Multidisciplinary Journal, 6, 1-55.

https://doi.org/10.1080/10705519909540118 
Jacobson, N. S., Martell, C. R., \& Dimidjian, S. (2006). Behavioral activation treatment for depression: Returning to contextual roots. Clinical Psychology: Science and Practice, 8, 255-270. https://doi.org/10.1093/clipsy.8.3.255

Jang, K., Park, N., \& Song, H. (2016). Social comparison on Facebook: Its antecedents and psychological outcomes. Computers in Human Behavior, 62, 147-154. https://doi.org/10.1016/j.chb.2016.03.082

Joinson, A. N. (2008). "Looking at," "looking up," or "keeping up" with people? Motives and uses of Facebook. Paper presented at the 26th Annual SIGCHI Conference on Human Factors in Computing Systems.

Judge, T. A., \& Bono, J. E. (2000). Five-factor model of personality and transformational leadership. Journal of Applied Psychology, 85, 751-765. https://doi.org/10.1037/0021-9010.85.5.751

Junco, R. (2012). The relationship between frequency of Facebook use, participation in Facebook activities, and student engagement. Computers \& Education, 58, 162-171. https://doi.org/10.1016/j.compedu.2011.08.004

Kardefelt-Winther, D. (2014). A conceptual and methodological critique of internet addiction research: Towards a model of compensatory Internet use. Computers in Human Behavior, 31, 351-354.

https://doi.org/10.1016/j.chb.2013.10.059

Konstabel, K., Lönnqvist, J.-E., Walkowitz, G., Konstabel, K., \& Verkasalo, M. (2012). The 'Short Five' (S5): Measuring personality traits using comprehensive single items. European Journal of Personality, 26, 13-29.

https://doi.org/10.1002/per.813

Konstabel, K., Lonnqvist, J. E., Leikas, S., Garcia Velazquez, R., Qin, H., Verkasalo, M., \& Walkowitz, G. (2017). Measuring single constructs by single items: Constructing an even shorter version of the "Short Five" personality inventory. PLoS One, 12(8), e0182714. https://doi.org/10.1371/journal.pone.0182714

Krasnova, H., Wenninger, H., Widjaja, T., \& Buxmann, P. (2013, 27.02.-01.03.2013.). Envy on Facebook: a hidden threat to users' life satisfaction? Paper presented at the 11th International Conference on Wirtschaftsinformatik (WI2013), Leipzig, Germany.

Kross, E., Verduyn, P., Demiralp, E., Park, J., Lee, D. S., \& Lin, N. (2013). Facebook use predicts declines in subjective well-being in young adults. PLoS One, 8(8), e69841. https://doi.org/10.1371/journal.pone.0069841

Kuss, D. J., \& Griffiths, M. D. (2011). Online social networking and addiction-A review of the psychological literature. International Journal of Environmental Research and Public Health, 8, 3528-3552.

https://doi.org/10.3390/ijerph8093528

Lee, S. Y. (2014). How do people compare themselves with others on social network sites?: The case of Facebook. Computers in Human Behavior, 32, 253-260. https://doi.org/10.1016/j.chb.2013.12.009

Lehtmets, J. (2017). Sotsiaalse võrdluse seosed sotsiaalmeedia kasutamise, isiksuse ning eluga rahuloluga Eesti üliõpilaste näitel [Social comparison and its links to social media usage, personality traits and life satisfaction on the example of Estonian university students]. (Research paper), Institute of Psychology, University of Tartu, Tartu.

MacKinnon, D. P. (2008). Introduction to statistical mediation analysis. New York, NY: Routledge Academic.

Mazer, J. P., Murphy, R. E., \& Simonds, C. J. (2007). I'll see you on "Facebook": The effects of computer-mediated teacher self-disclosure on student motivation, affective learning, and classroom climate. Communication Education, 56, 1-17. https://doi.org/10.1080/03634520601009710

McCrae, R. R., Costa, P. T., Ostendorf, F., Angleitner, A., Hřebíčková, M., Avia, M. D., . . Smith, P. B. (2000). Nature over nurture: Temperament, personality, and life span development. Journal of Personality and Social Psychology, 78, 173-186. https://doi.org/10.1037/0022-3514.78.1.173 
McEwan, B. (2013). Sharing, caring, and surveilling: An actor-partner interdependence model examination of Facebook relational maintenance strategies. Cyberpsychology, Behavior, and Social Networking, 16, 863-869. https://doi.org/10.1089/cyber.2012.0717

Mehdizadeh, S. (2010). Self-presentation 2.0: Narcissism and self-esteem on Facebook. Cyberpsychology, Behavior, and Social Networking, 13, 357-364. https://doi.org/10.1089/cyber.2009.0257

Muise, A., Christofedes, E., \& Desmaris, S. (2009). More information than you ever wanted: Does Facebook bring out the green-eyed monster of jealousy? CyberPsychology \& Behavior, 12, 441-444.

https://doi.org/10.1089/cpb.2008.0263

Mussweiler, T., Ruter, K., \& Epstude, K. (2006). The why, who, and how of social comparison: A social-cognition perspective. In S. Guimond (Ed.), Social comparison and social psychology: Understanding cognition, intergroup relations, and culture (pp. 33-54). New York, NY: Cambridge University Press.

Muthén, L. K., \& Muthén, B. O. (1998-2017). Mplus user's guide (8th ed.). Los Angeles, CA: Muthén \& Muthén.

NapoleonCat. (2017). Facebook and Instagram user demographics in Estonia - August 2017. Retrieved from https://napoleoncat.com/blog/en/facebook-and-instagram-user-demographics-in-estonia-august-2017/

Odgers, C. (2018). Smartphones are bad for some teens, not all. Nature, 554(7693), 432-434.

https://doi.org/10.1038/d41586-018-02109-8

Ozer, D. J., \& Benet-Martinez, V. (2006). Personality and the prediction of consequential outcomes. Annual Review of Psychology, 57, 401-421. https://doi.org/10.1146/annurev.psych.57.102904.190127

Ozimek, P., \& Förster, J. (2017). The impact of self-regulatory states and traits on Facebook use: Priming materialism and social comparisons. Computers in Human Behavior, 71, 418-427.

https://doi.org/10.1016/j.chb.2017.01.056

Pahker, A.-K. (2016). Facebooki aktiivse-passiivse ja avaliku-privaatse kasutamise seosed enesehinnangu ja isiksuseomadustega [Active-Passive and Public-Private Facebook Usage and Its Relations to Self-Esteem and Personality]. (Research paper), Institute of Psychology, University of Tartu, Tartu.

Papacharissi, Z., \& Mendelson, A. (2011). Toward a new(er) sociability: Uses, gratifications, and social capital on Facebook. In S. Papathanassopoulos (Ed.), Media perspectives for the 21st century (pp. 212-230). London, UK: Routledge.

Park, N., Kee, K. F., \& Valenzuela, S. (2009). Being immersed in social networking environment: Facebook groups, uses and gratifications, and social outcomes. CyberPsychology \& Behavior, 12, 729-733.

https://doi.org/10.1089/cpb.2009.0003

Przybylski, A. K., Murayama, K., DeHaan, C. R., \& Gladwell, V. (2013). Motivational, emotional, and behavioral correlates of fear of missing out. Computers in Human Behavior, 29, 1841-1848.

https://doi.org/10.1016/j.chb.2013.02.014

Qiu, L., Lin, H., Leung, A. K., \& Tov, W. (2012). Putting their best foot forward: emotional disclosure on Facebook. Cyberpsychology, Behavior, and Social Networking, 15, 569-572. https://doi.org/10.1089/cyber.2012.0200

R Core Team. (2017). R: A language and environment for statistical computing (Version 3.2.3.) [Software]. Vienna, Austria: R Core Team. Available from https://www.r-project.org/

Ross, C., Orr, E. S., Sisic, M., Arseneault, J. M., Simmering, M. G., \& Orr, R. R. (2009). Personality and motivations associated with Facebook use. Computers in Human Behavior, 25, 578-586.

https://doi.org/10.1016/j.chb.2008.12.024 
Ryan, T., Allen, K. A., Gray, D. L., \& McInerney, D. M. (2017). How social are social media? A review of online social behaviour and connectedness. Journal of Relationships Research, 8(e8), 1-8. Advanced online publication.

https://doi.org/10.1017/jrr.2017.13

Ryan, T., Chester, A., Reece, J., \& Xenos, S. (2014). The uses and abuses of Facebook: A review of Facebook addiction. Journal of Behavioral Addictions, 3, 133-148. https://doi.org/10.1556/JBA.3.2014.016

Ryan, T., \& Xenos, S. (2011). Who uses Facebook? An investigation into the relationship between the Big Five, shyness, narcissism, loneliness, and Facebook usage. Computers in Human Behavior, 27, 1658-1664.

https://doi.org/10.1016/j.chb.2011.02.004

Saklofske, D. H., Kelly, I. W., \& Janzen, B. L. (1995). Neuroticism, depression, and depression proneness.

Personality and Individual Differences, 18, 27-31. https://doi.org/10.1016/0191-8869(94)00128-f

Schachter, S. (1959). The psychology of affiliation. Stanford, CA: Stanford University Press.

Scott, G. G., \& Ravenscroft, K. (2017). Bragging on Facebook: The interaction of content source and focus in online impression formation. Cyberpsychology, Behavior, and Social Networking , 20, 58-63.

https://doi.org/10.1089/cyber.2016.0311

Shaw, A. M., Timpano, K. R., Tran, T. B., \& Joormann, J. (2015). Correlates of Facebook usage patterns: The relationship between passive Facebook use, social anxiety symptoms, and brooding. Computers in Human Behavior, 48, 575-580. https://doi.org/10.1016/j.chb.2015.02.003

Song, H., Cramer, E. M., \& Park, N. (2018). Cultural differences in social comparison on Facebook. Behaviour \& Information Technology, 38, 1-12. https://doi.org/10.1080/0144929x.2018.1519037

Song, H., Zmyslinski-Seelig, A., Kim, J., Drent, A., Victor, A., Omori, K., \& Allen, M. (2014). Does Facebook make you lonely?: A meta analysis. Computers in Human Behavior, 36, 446-452. https://doi.org/10.1016/j.chb.2014.04.011

Specht, J., Egloff, B., \& Schmukle, S. C. (2011). Stability and change of personality across the life course: The impact of age and major life events on mean-level and rank-order stability of the Big Five. Journal of Personality and Social Psychology, 101, 862-882. https://doi.org/10.1037/a0024950

Swickert, R. J., Hittner, J. B., Harris, J. L., \& Herring, J. A. (2002). Relationships among Internet use, personality, and social support. Computers in Human Behavior, 18, 437-451. https://doi.org/10.1016/s0747-5632(01)00054-1

Thornton, D. A., \& Arrowood, A. J. (1966). Self-evaluation, self-enhancement, and the locus of social comparison. Journal of Experimental Social Psychology, 1(Suppl. 1), 40-48. https://doi.org/10.1016/0022-1031(66)90064-3

Tokunaga, R. S. (2011). Social networking site or social surveillance site? Understanding the use of interpersonal electronic surveillance in romantic relationships. Computers in Human Behavior, 27, 705-713.

https://doi.org/10.1016/j.chb.2010.08.014

Tosun, L. P. (2012). Motives for Facebook use and expressing "true self" on the Internet. Computers in Human Behavior, 28, 1510-1517. https://doi.org/10.1016/j.chb.2012.03.018

Valenzuela, S., Park, N., \& Kee, K. F. (2008). Is there social capital in a social network site?: Facebook use and college students' life satisfaction, trust, and participation. Journal of Computer-Mediated Communication, 14, 875901. https://doi.org/10.1111/j.1083-6101.2009.01474.x

Van Der Zee, K. I., Buunk, B. P., Sanderman, R., Botke, G., \& Van Den Bergh, F. (1999). The Big Five and identification-contrast processes in social comparison in adjustment to cancer treatment. European Journal of Personality, 13, 307-326. 
Varghese, L., \& Barber, L. K. (2017). A preliminary study exploring moderating effects of role stressors on the relationship between Big Five personality traits and workplace cyberloafing. Cyberpsychology: Journal of Psychosocial Research on Cyberspace, 11(4), article 4. https://doi.org/10.5817/cp2017-4-4

Verduyn, P., Lee, D. S., Park, J., Shablack, H., Orvell, A., Bayer, J., . . Kross, E. (2015). Passive Facebook usage undermines affective well-being: Experimental and longitudinal evidence. Journal of Experimental Psychology: General, 144, 480-488. https://doi.org/10.1037/xge0000057

Verduyn, P., Ybarra, O., Résibois, M., Jonides, J., \& Kross, E. (2017). Do social network sites enhance or undermine subjective well-being? A critical review. Social Issues and Policy Review, 11, 274-302.

https://doi.org/10.1111/sipr.12033

Vogel, E. A., Rose, J. P., Okdie, B. M., Eckles, K., \& Franz, B. (2015). Who compares and despairs? The effect of social comparison orientation on social media use and its outcomes. Personality and Individual Differences, 86, 249-256. https://doi.org/10.1016/j.paid.2015.06.026

Wallace, L., James, T. L., \& Warkentin, M. (2017). How do you feel about your friends? Understanding situational envy in online social networks. Information \& Management, 54, 669-682. https://doi.org/10.1016/j.im.2016.12.010

Watson, D., Clark, L. A., \& Carey, G. (1988). Positive and negative affectivity and their relation to anxiety and depressive disorders. Journal of Abnormal Psychology, 97, 346-353. https://doi.org/10.1037/0021-843x.97.3.346

Wills, T. A. (1981). Downward comparison principles in social psychology. Psychological Bulletin, 90, 245-271. https://doi.org/10.1037/0033-2909.90.2.245

Wirth, R. J., \& Edwards, M. C. (2007). Item factor analysis: Current approaches and future directions. Psychological Methods, 12, 58-79. https://doi.org/10.1037/1082-989X.12.1.58

Yang, T. (2017). The mediation role of passive SNS use between social comparison orientation and envy. Advances in Psychology, 07(05), 691-697.

Ybema, J. F., \& Buunk, B. P. (1995). Affective responses to social comparison: A study among disabled individuals. British Journal of Social Psychology, 34, 279-292. https://doi.org/10.1111/j.2044-8309.1995.tb01064.x 


\section{Appendix}

Supplementary Table A1. Spearman Correlations between Variables (with p-values in Parentheses).

\begin{tabular}{|c|c|c|c|c|c|c|c|c|c|c|c|}
\hline Variable & & & & & & & & & & & \\
\hline 1. Active-public & 1 & & & & & & & & & & \\
\hline 2. Active-private & $.022(.691)$ & 2 & & & & & & & & & \\
\hline 3. Passive (5 items) & $\begin{array}{c}.294 \\
(<.001)\end{array}$ & $\begin{array}{c}.288 \\
(<.001)\end{array}$ & 3 & & & & & & & & \\
\hline 4. Passive (4 items) & $\begin{array}{c}.268 \\
(<.001)\end{array}$ & $\begin{array}{c}.239 \\
(<.001)\end{array}$ & $\begin{array}{c}.946 \\
(<.001)\end{array}$ & 4 & & & & & & & \\
\hline 5. Neuroticism & $.021(.714)$ & $.081(.149)$ & $\begin{array}{c}.256 \\
(<.001)\end{array}$ & $\begin{array}{c}.225 \\
(<.001)\end{array}$ & 5 & & & & & & \\
\hline 6. Extraversion & $.143(.011)$ & $\begin{array}{c}.184 \\
(.001)\end{array}$ & $\begin{array}{l}-.065 \\
(.247)\end{array}$ & $-.053(.347)$ & $\begin{array}{c}-.463 \\
(<.001)\end{array}$ & 6 & & & & & \\
\hline $\begin{array}{l}\text { 7. Openness to } \\
\text { experience }\end{array}$ & $.096(.088)$ & $\begin{array}{l}.124 \\
(.027)\end{array}$ & $\begin{array}{l}-.007 \\
(.900)\end{array}$ & $-.029(.604)$ & $\begin{array}{l}-.094 \\
(.095)\end{array}$ & $\begin{array}{c}.380 \\
(<.001)\end{array}$ & 7 & & & & \\
\hline 8. Agreeableness & $-.079(159)$ & $\begin{array}{l}-.017 \\
(.759)\end{array}$ & $\begin{array}{l}-.045 \\
(.429)\end{array}$ & $-.048(.396)$ & $\begin{array}{c}-.209 \\
(<.001)\end{array}$ & $\begin{array}{l}-.022 \\
(.699)\end{array}$ & $\begin{array}{c}.161 \\
(.004)\end{array}$ & 8 & & & \\
\hline 9. Conscientiousness & $.006(.917)$ & $\begin{array}{l}-.025 \\
(.657)\end{array}$ & $\begin{array}{l}-.073 \\
(.196)\end{array}$ & $-.086(.125)$ & $\begin{array}{c}-.455 \\
(<.001)\end{array}$ & $\begin{array}{c}.333 \\
(<.001)\end{array}$ & $\begin{array}{l}.070 \\
(.211)\end{array}$ & $\begin{array}{l}.127 \\
(.024)\end{array}$ & 9 & & \\
\hline $\begin{array}{l}\text { 10. Social } \\
\text { comparison } \\
\text { orientation }\end{array}$ & $.025(.651)$ & $.116(.038)$ & $\begin{array}{c}.371 \\
(<.001)\end{array}$ & $\begin{array}{c}.349 \\
(<.001)\end{array}$ & $\begin{array}{c}.400 \\
(<.001)\end{array}$ & $\begin{array}{l}-.098 \\
(.080)\end{array}$ & $\begin{array}{l}-.077 \\
(.169)\end{array}$ & $\begin{array}{l}-.075 \\
(.183)\end{array}$ & $\begin{array}{l}-.191 \\
(.001)\end{array}$ & 10 & \\
\hline 11. Age & $.184(.001)$ & $.025(.662)$ & $.004(.946)$ & $.010(.865)$ & $\begin{array}{l}-.070 \\
(.212)\end{array}$ & $\begin{array}{c}.050 \\
(.377)\end{array}$ & $\begin{array}{c}.071 \\
(.206)\end{array}$ & $\begin{array}{c}.037 \\
(.510)\end{array}$ & $\begin{array}{c}.094 \\
(.094)\end{array}$ & $\begin{array}{l}-.099 \\
(.077)\end{array}$ & 11 \\
\hline 12. Gender ${ }^{a}$ & $.028(.615)$ & $\begin{array}{l}-.001 \\
(.992)\end{array}$ & $\begin{array}{l}-.064 \\
(.259)\end{array}$ & $-.067(.235)$ & $\begin{array}{l}-.056 \\
(.321)\end{array}$ & $\begin{array}{l}-.022 \\
(.695)\end{array}$ & $\begin{array}{l}-.135 \\
(.016)\end{array}$ & $\begin{array}{l}-.053 \\
(.345)\end{array}$ & $\begin{array}{c}.047 \\
(.408)\end{array}$ & $\begin{array}{l}-0.49 \\
(.387)\end{array}$ & $\begin{array}{l}-.091 \\
(.104)\end{array}$ \\
\hline
\end{tabular}

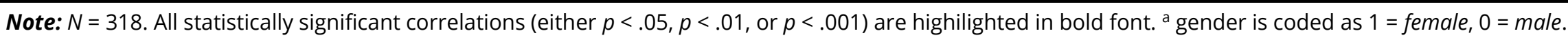




\section{Correspondence to:}

Graham G. Scott

School of Media, Culture, \& Society

University of the West of Scotland

Paisley, PA1 2BE

United Kingdom

Email: graham.scott(at)uws.ac.uk

t: $+44(0) 1418483830$

Editorial record: First submission received on June 6, 2018. Revisions received on October 25, 2018, and January 9, 2019. Accepted for publication on January 15, 2019.

\section{About Authors}

Dmitri Rozgonjuk (M.A. University of Tartu, 2015) is a PhD researcher in Psychology at the University of Tartu, Estonia, and a Fulbright visiting student researcher at the Department of Psychology at the University of Toledo, $\mathrm{OH}, \mathrm{USA}$. His main interests include the impact of digital device and social media usage on subjective well-being, mental health, and academic outcomes.

Tracii Ryan (Ph.D. RMIT University, 2015) is a Research Fellow in the Faculty of Education at Monash University and the Melbourne Centre for the Study of Higher Education at The University of Melbourne. Her research expertise bridges the disciplines of cyberpsychology and education, with a specific focus on the motivations and outcomes of social media use, individual differences, and assessment feedback.

Joosep Kristjan Kuljus (B.A. University of Tartu, 2017) was an undergraduate student in Psychology at the University of Tartu, Estonia. Part of this study is based on the data collected for his undergraduate research project.

Karin Täht (Ph.D. University of Tartu, 2012) is a research fellow (psychometrics) in the Department of Psychology at the University of Tartu, Estonia. Her research has mainly been connected with educational psychology.

Graham G. Scott (Ph.D. University of Glasgow, 2009) is a lecturer in psychology at the University of the West of Scotland whose primary research interests are in the experimental investigation of online impression formation, and how individual differences drive self-presentation and communication behaviour on social media. 